Review

\title{
Cereal yield response to conservation agriculture practices in drylands of West Africa: A quantitative synthesis
}

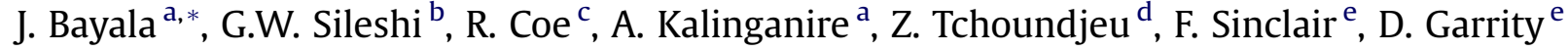 \\ ${ }^{a}$ World Agroforestry Centre, West and Centre Africa Regional Office, Sahel Node, BP E5118, Bamako, Mali \\ ${ }^{\mathrm{b}}$ World Agroforestry Centre, South Africa Regional Office, Lilongwe, Malawi \\ ${ }^{\mathrm{c}}$ World Agroforestry Centre, East Africa Regional Office, Tanzania \\ ${ }^{\mathrm{d}}$ World Agroforestry Centre, West and Centre Africa Regional Office, Yaoundé, Cameroon \\ ${ }^{\mathrm{e}}$ World Agroforestry Centre, Headquarters, Nairobi, Kenya
}

\section{A R T I C L E I N F O}

\section{Article history:}

Received 13 March 2011

Received in revised form

2 August 2011

Accepted 11 October 2011

Available online 4 November 2011

\section{Keywords:}

Coppicing trees

Cover crops

Mean difference in yield

Parklands

Soil and water conservation

\begin{abstract}
A B S T R A C T
To address the decline in crop productivity in the drylands of West Africa, many initiatives have focused on combating soil degradation. Various practices including (1) parkland trees associated with crops, (2) coppicing trees, (3) green manure, (4) mulching, (5) crop rotation and intercropping, and (6) traditional soil/water conservation have been tested. The present study attempts to provide a comprehensive, quantitative synthesis of existing reports on the effect of conservation agriculture (CA) practices on crop yield response in Burkina Faso, Mali, Niger and Senegal. Out of a total of 155 reports found, 63 fulfilled all the appropriate criteria to be included in the meta-analysis of the effect of various conservation agriculture practices on the yield response of maize, millet and sorghum. The study revealed significant variability in cereal yield response (and hence risk) with all the practices examined. Despite the variability, the mean effects of the six CA practices on crop yield were more positive than negative except with parkland trees. However, for this last practice, species like Faidherbia albida exerts more positive impact on crop yield. Yield increases relative to the control were higher with green manure and mulching than with coppicing trees and parklands. Increases in yield in the six CA practices were higher on low to medium productivity sites for maize, millet and sorghum. Coppicing trees and rotations improved yields when the rainfall is $>800 \mathrm{~mm}$ whereas the opposite happens with parkland and soil-water conservation measures. Mulching performed better when the rainfall is $<600 \mathrm{~mm}$. The variability (and hence yield risks) calls for more understanding of the processes and application of appropriate tree management to reduce crop yield losses while still providing products (fruits, leaves, wood, etc.) and services (soil carbon building up) for long-term sustainability of the production systems in drylands of West Africa.
\end{abstract}

(c) 2011 Elsevier Ltd. All rights reserved.

\section{Introduction}

Dryland areas are terrestrial regions falling within arid, semi-arid, and dry sub-humid zones, whose boundaries are defined by the ratio of mean annual precipitation to mean annual potential evapotranspiration (Hassan et al., 2005). The definition of drylands has been adopted by the United Nations Convention to Combat Desertification to describe lands where problems with land degradation should be focused and where methods for attaining sustainable development should be promoted, considering their ecological fragility (Hassan et al., 2005). The drylands of West Africa cover nearly 1.5 million $\mathrm{km}^{2}$ between the Sahara desert in the north

\footnotetext{
* Corresponding author. Tel.: +223 202350 00; fax: +223 20228683 .

E-mail address: j.bayala@cgiar.org (J. Bayala).
}

and the Sudanian savannah in the south. Thus the drylands include much of the Sahel, the belt running across the southern fringe of the Sahara. Annual rainfall in the Sahel varies from $200 \mathrm{~mm}$ in the north to $1000 \mathrm{~mm}$ in the south (Bationo et al., 2006) with high year to year variability and longer term trends throughout the period of available records (Dai et al., 2004; Guichard et al., 2010). The inhabitants of the area are farmers and pastoralists who suffer most from rainfall uncertainty and risks of drought. The population growth rate, estimated at $3 \%$ per annum, exceeds the food production growth rate of only $2 \%$ per annum (UNDP, 2006). The traditional crop-tree-livestock systems of the parklands, which cover much of the region, are rapidly degrading. Woody biodiversity and cover is being lost (Gijsbers et al., 1994), and soil fertility is declining from already low levels through cropping practices that mine nutrients and expose the soil to erosion (Bationo et al., 2003). Population growth is probably the most important driver underlying these 
trends (FAO, 2004). The restoration and protection of the agricultural lands is vital for the future welfare of the millions of people living in the drylands of West Africa (Bonkoungou et al., 1998). In order to achieve the Millennium Development Goals, agricultural productivity in these countries will need to dramatically increase (at a rate of about $6 \%$ per year), without harming the environment (Kandji et al., 2006). Unfortunately, the scarcity of data about the productivity and functioning of the agricultural lands particularly under changing climatic and socio-economic conditions hinders progress in the development of sustainable agriculture in the drylands of West African zone.

Despite such difficult situation, a growing number of cases document success in improving crop and livestock production, and in environmental management (Reij and Smaling, 2008). The Maradi and Zinder regions of Niger (Reij and Smaling, 2008) and the Central Plateau of Burkina Faso (Belemviré et al., 2008) offer very good examples of success stories even though localized. Farmers have been protecting and managing natural regeneration on their cultivated fields, which have resulted in a substantial re-greening of parts of the Sahel (Reij and Smaling, 2008; Garrity et al., 2010).

All these experiences have put a focus in combating soil degradation or reclaiming degraded soils through the application of conservation agriculture (CA) practices. In this context, we define 'conservation agriculture' as "farming practices that contribute to three key principles of reducing soil disturbance, maintaining soil cover and practicing crop rotation/association (FAO, 2009)". These practices are more specifically Conservation Agriculture With Trees (CAWT) when a woody perennial is used as a technological element within the practice (Bayala et al., 2011). These practices can improve soil carbon contents, reduce erosion, increase water infiltration and water hold capacity, increase nutrient stocks, etc. These soil changes have the potential to enhance agricultural productivity, while at the same time contributing to natural resources conservation under changing weather patterns (ACT, 2008; Rockström et al., 2009). Experiences from east and southern Africa indicate that for smallholder farmers in dryland agro-ecosystems, conservation agriculture first and foremost constitutes a water harvesting strategy (Rockström et al., 2009). Various conservation agriculture practices including crop residue management, mulching, cover cropping, parkland tree management and traditional soil/water conservation technologies such as zaï, half-moon, earth and stone bunds, grass strips have been widely used in some particular areas in the Sahel with some level of success. Parkland tree species together with soil and water conservation practices are increasingly being promoted in various development projects including the re-greening of the Sahel initiative (Reij et al., 2005; Coghlan, 2006) and combating desertification (Kirmse and Norton, 1984). In this study we are particularly interested in determining the effect of these practices on crop yield.

Wezel and Rath (2002) have tried to synthesize the existing information on traditional and modern practices used to combat soil degradation in semi-arid West Africa countries. However, their synthesis was qualitative and failed to show a clear pattern and the magnitude of crop response using these techniques. More recent reviews on conservation agriculture were published by Traoré and Zougmoré (2008) for Burkina Faso alone and Thiombiano and Meshack (2009) for Africa, but these reviews were also narrative. For more humid areas, several attempts have been made to review and synthesize the knowledge on the functions, processes and capabilities of planted fallows and green manure legumes in Africa (Drechsel et al., 1996; Rao et al., 1998; Sanchez, 1999; Szott et al., 1999; Hauser et al., 2006) and their effects on crop productivity (Sileshi et al., 2008). Most studies reported positive effects on soil fertility but the effects on crop productivity were more debatable. This is due to highly variable results of individual studies making it difficult to show pattern using narrative reviews and the use of faulty methodology with the risks of both type I (false positive error occurs when a statistical test rejects a true null hypothesis) and type II (false negative error occurs when the test fails to reject a false null hypothesis) errors (Sileshi et al., 2008). The lack of quantitative synthesis in terms of the nature and magnitude of response and the contrasting results reported regarding the potential of conservation agriculture call for a comprehensive and quantitative analysis. Therefore, the primary goal of this analysis is to provide a synthesis of available data on crop yield response to conservation agriculture practices across different locations, types of soils and climate conditions. This will aid formulation of evidence-based practical guidelines, interventions and enhancing crop production through conservation agriculture with trees where appropriate in drylands. We conducted a meta-analysis with the overall aim of assessing whether or not there is a consistent evidence for yield benefits using conservation agriculture with or without trees in the drylands of West Africa. The specific objectives of this analysis were to (1) provide a comprehensive, quantitative synthesis of existing reports on the effect of conservation agriculture with and without trees on crop yield in general, and (2) conduct parametric estimation of the magnitude of yield response.

\section{Methods}

\subsection{Definitions of the geographic area and practices studied}

This analysis focuses on Burkina Faso, Mali, Niger, and Senegal. The geographic area of the study sites covers the Sahel and the dry sub-humid zones (up to $1200 \mathrm{~mm}$ rainfall) in these countries. Climatically the Sahel is defined as the area between the 200 and $600 \mathrm{~mm}$ isohyets (Heinrigs and Perret, 2009). Halfway between these isohyets is the limit of the rain-fed agricultural area. The wet season lasts only three to seven months in the studied area. High inter-annual and decadal variability and droughts are very common (Dai et al., 2004; Guichard et al., 2010). This zone is characterized by subsistence agriculture producing cereals, notably sorghum and millet, often on degraded soils and entirely depending on rain. The vulnerability to droughts and soil degradation makes more intensive farming practices risky in the studied area.

The practices included in this analysis are various components of conservation agriculture, which combines principles of minimum soil disturbance (reduced or no tillage), permanent soil cover, and rotations where farmers choose what is best for them (Thiombiano and Meshack, 2009). We adopt a broader view of conservation agriculture (than its current definition) as a concept for natural resource-saving that strives to achieve acceptable profits with high and sustained production levels while concurrently conserving the environment (FAO, 2009). Hence, for the sake of this analysis we chose those practices that qualify for ensuring minimum soil disturbance, permanent soil cover (either through crop residues, herbaceous cover crops, shrubs or trees) and involving rotations (either with food crops, cover crops or trees). These were then grouped into the following categories for the purpose of the meta-analysis.

1. Parkland trees associated with crops: Parklands are anthropogenic vegetation assemblages derived from savannas ecosystems (Maranz, 2009). Farmers usually protect naturally regenerating trees during tillage operations, keeping tree density low so that canopy cover is not continuous. Farmer managed natural regeneration (FMNR), which consists of selecting and thinning stems which sprout from indigenous tree and shrub stumps or appear as seedlings, has been actively used to obtain significant re-growth of trees on crop fields and 
fallow fields (Gijsbers et al., 1994; Reij et al., 2009). Therefore, parklands are a reflection of a slow process of species selection and density management of indigenous trees by farmers (Mortimore and Turner, 2005). The main parkland species in the Sahel are Acacia spp., Adansonia digitata L., Anogeissus leiocarpus (DC.) Guill. et Perr., Borassus aethiopum Mart., Faidherbia albida (Del.) Chev., Ficus spp., Hyphaene thebaica (L.) Mart., Lannea microcarpa Engl. et K. Krause, Parkia biglobosa (Jacq.) R. Br. ex G. Don, Pterocarpus erinaceus Poir., Pterocarpus lucens Guill. et Perr., Sclerocarya birrea (A. Rich.) Hochst., Tamarindus indica L., Terminalia laxiflora Engl., Vitellaria paradoxa C. F. Gaertn and Ziziphus mauritiana Lam.

2. Coppicing trees: This includes coppicing trees and shrubs (e.g. Acacia auriculiformis A. Cunn. ex Benth., Acacia mangium Willd., Acacia colei Maslin \& L. Thomson, Acacia tumida Benth., Albizia lebbeck (L.) Benth., Azadirachta indica A. Juss., Combretum lecardii Engl. et Diels, Gliricidia sepium (Jacq.) Walp., Guiera senegalensis J. F. Gmel., Leucaena leucocephala (Lam.) de Wit, Piliostigma reticulatum (DC.) Hochst., Prosospis africana (Guill. et Perr.) Taub., etc.) used for poles as well as planted fallows of various leguminous species for production of twig and leaf biomass to be used for soil fertility replenishment. The distinction from 'parklands' is that trees are regularly cut to ground level and allowed to re-grow. Tree densities are typically much higher than in parklands.

3. Green manure is the biomass from herbaceous cover crops (Crotolaria spp., Mucuna cochincinensis (Lour.) A. Chev., Mucuna pruriens (L.) DC., Stylosanthes hamata (L.) Taub., Tephrosia vogelii Hook.f., etc.) grown to be turned under soil as soil amendment and nutrient sources for subsequent crops. Usually the cover crop is established through relay cropping with the staple food crop.

4. Mulching: Mulching consists of covering the ground with a layer of plant materials in order to conserve soil water, to stimulate the activity of soil biota (e.g. termites) and to reclaim a degraded soil for crop production. This involves use of a range of plant materials (wild grass, crop residues or tree biomass, either leguminous or not) in the semi-arid area and sometimes in association with soil and water conservation techniques using crop residues or prunings from trees and shrubs or a mixture.

5. Rotations and crop associations: Legumes (e.g. cowpea, groundnut) are frequently intercropped or rotated with cereals. In order to improve soil fertility and animal nutrition, several cereal-legume associations and cover crops (e.g. mucuna, stylo, crotalaria, etc.) are found in farmer's fields. Sorghum-cowpea millet-cowpea, maize-cowpea, and sorghum-groundnuts associations are commonly found on farmers' fields of the study area.

6. Soil and water conservation practices: These include traditional practices such as zaï, half-moon, stone and earth bunds and grass strips. These techniques aimed at increasing infiltration, soil moisture retention, soil organic matter content and improving soil structure besides reducing soil erosion. Zaï is widely practiced in the Sudano-Sahelian zones of Burkina Faso, Mali and Niger (Adam et al., 2006; Belemviré et al., 2008; Bengaly, 2008). The zaï pits are filled with organic matter and annual crops such as millet or sorghum are planted. The zaï pits can be combined with contour or stone bunds and tree planting (UN-DESA, 2005). On bare soils in the Sahel, zaï have been shown to increase the activity of termites which increase woody plant regeneration and speed up the restoration of degraded areas (Mando et al., 1999; Sileshi et al., 2010). Half-moon is minimum tillage practice where a basin of half-circle shape is excavated and the soil laid out in a semicircular pad flattened on the top. This can be combined with application of compost and animal manure to improve soil fertility. Stone bunds are formed of one or several lines of stones constructed along the contour lines with a height of about $25 \mathrm{~cm}$. These barriers slow down water runoff and enhance its infiltration rates. Silt trapped on the higher side of the barrier forms natural terraces. Earthen bunds are constructed along the contour lines with the earth taken from the lower side and they are twice wide as they are high. They play the same role as stone bunds except they are not permeable and pond runoff water. The spacing of both stone and earth bunds depends on soil characteristics, rainfall and the slope. They can both be associated with vegetative material to reinforce them and form a living barrier over a period of time. Grass strips of $3 \mathrm{~m}$ width with a spacing of $50 \mathrm{~m}$ between strips are also established in the field to reduce runoff and erosion. Species used include Digitaria exilis (Kippist) Stapf. (fonio), Brachiaria ruziziensis Germ. and C.M. Evrard, S. hamata (L.) Taub., Andropogon gayanus Kunth or association of for instance $B$. ruziziensis and $S$. hamata. Some grasses such as A. gayanus have a longer residence time and withstand fire and grazing and therefore is the preferred species. For almost all of these "physical" approaches and infrastructures, there is a need for external subsidies (food for work, paid labour, etc.) to be set up given the enormous physical efforts to conduct the work.

\subsection{Data collection}

Data for the meta-analysis were compiled from publications and reports. The availability of such data limits what can be collected. The staple food crops in the Sahel are the cereals millet, sorghum and maize, and most information about the effects of CAWT is for these crops. For this reason the foci of the present analyses were grain and straw dry matter yields of millet, sorghum and maize. Grain yield is a good measure of productivity as the plant itself integrates across all factors, including soil, climate, pests and diseases, which affect productivity. But when dealing with conservation agriculture, the recycling of crop residues for soil conservation or fertility enhancement is also important and therefore the dry weight of the crop residues (i.e. straw) was also considered in the analysis. In addition, livestock are an integral part of most Sahelian farming systems and crop residues are important sources of animal fodder.

The following criteria were used for a publication to be included in the analysis:

(1) The data are from one of the four countries Burkina Faso, Mali, Niger and Senegal;

(2) The publication contains reported crop yield of one or more of the 6 CA practices and a corresponding control plot where the practice was not applied, with mean yields either reported numerically or graphically. The yield data from rotations were not time-averaged by including years when other crops were grown while data from tree-based systems were based on total area;

(3) Data were from well designed and replicated experiments or observational studies either on a research station or on farmers' fields.

The studies included were located by searching through computer library databases (ICRAF, FAO, and Google Scholar). However, this alone does not provide a comprehensive search and therefore it was followed up with supplementary searches for 'grey' literature such as student theses and unpublished research reports. In many cases although research is conducted data are often not published in scientific journals once reports have been produced. Therefore the first author travelled to the four countries to collect student theses and unpublished research reports. Tables 1 and 2 
Table 1

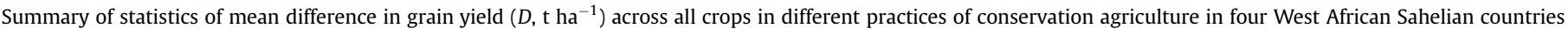
(Burkina Faso, Mali, Niger and Senegal).

\begin{tabular}{|c|c|c|c|c|c|c|}
\hline & Parkland trees & Coppicing trees & Green manure & Mulching & Rotation-association & Soil \& water conservation \\
\hline Number of references $(N)$ & 15 & 12 & 9 & 13 & 6 & 15 \\
\hline Number of pairs $(k)$ & 64 & 97 & 50 & 94 & 182 & 126 \\
\hline Mean & 0.02 & 0.34 & 0.76 & 0.35 & 0.31 & 0.35 \\
\hline Upper quartile (75\%) & 0.25 & 0.40 & 0.92 & 0.60 & 0.60 & 0.60 \\
\hline Median (50\%) & 0.00 & 0.10 & 0.73 & 0.30 & 0.20 & 0.20 \\
\hline Lower quartile (25\%) & -0.20 & -0.10 & 0.30 & 0.10 & 0.00 & 0.10 \\
\hline Interquartile range & 0.45 & 0.50 & 0.62 & 0.50 & 0.60 & 0.60 \\
\hline$\%$ cases with $D \leq 0 \mathrm{tha}^{-1}$ & 65.6 & 44.3 & 16.0 & 23.4 & 29.1 & 20.6 \\
\hline$\%$ cases with $D \overline{0.1}-0.9 \mathrm{tha}^{-1}$ & 32.8 & 44.4 & 64.0 & 63.8 & 66.5 & 70.7 \\
\hline$\%$ cases with $D 1.0-2.0 \mathrm{t} \mathrm{ha}^{-1}$ & 1.6 & 5.1 & 16.4 & 12.8 & 4.4 & 8.7 \\
\hline$\%$ cases with $D>2.0 \mathrm{t} \mathrm{ha}^{-1}$ & 0.0 & 6.2 & 4.0 & 0.0 & 0.0 & 0.0 \\
\hline
\end{tabular}

give the practices included in this analysis and the number of references for each practice.

A total of 155 references that reported crop yield from conservation agriculture were found but only 63 fulfilled all the criteria listed above (Appendix 1). These publications covered the semi-arid to sub-humid agro-ecological zone of the drylands of the four countries with altitudes of study sites ranging from 200 to $600 \mathrm{~m}$ and rainfall from 380 to $1100 \mathrm{~mm}$ with unimodal rainfall pattern. In cases where the same data has been presented by the same author in two or more different publications, only one was included in this analysis. When data on more than one practice was available in the same publication or when data from different seasons and sites were reported, all were included. This yielded a total of 614 separate pairs of means (treatment and control) for grain yield and 444 pairs of means for straw yield. Some $55 \%$ of the studies came from on-station experiments and $45 \%$ from on-farm trials and observational studies. Over $90 \%$ of the on-station trials were laid out as randomized complete blocks and a few were split-plot and other designs. They had three to six replicates. On-farm experiments and observational studies mainly used farms as replicates. The management of crops was assumed to be similar in the treatment and control plots. It is further assumed that crop species and variety and treatment effects are not confounded, i.e. in each study the same crop species or variety was used in the treatment and control groups.

\subsection{Data analysis}

Data were converted to mean difference in yield of both grain and straw biomass. The mean difference in yield $(D)$ was defined as the difference in grain or straw dry matter yield between crops grown using a given conservation agriculture technology and the control of no such practice from the same study ( $D=\mathrm{Me}-\mathrm{Mc}$ ). Mean difference in yield data were analyzed by simple summary statistics and calculation of empirical cumulative distributions. Data on $D$ were further analyzed using mixed models fitted using Restricted Maximum Likelihood (REML). Besides null hypothesis testing, statistical inference was based on the predicted means and their $95 \%$ confidence intervals (CI). One of the advantages of $95 \% \mathrm{CI}$ over traditional hypothesis testing is the additional information they convey. The interpretation of the CIs is that if the same experiment was repeated many times, $95 \%$ of the time the $D$ estimate would fall within the upper and lower confidence limits associated with the mean (Gelman et al., 1995). The upper and lower bounds of the $\mathrm{CI}$ give information on how big or small the true effect might plausibly be. Mean $D$ for a given CA treatment was considered different from 0 if the $95 \% \mathrm{CI}$ did not include 0 .

A site productivity score was derived from the control yield for each crop as $1=<0.51 \mathrm{t} \mathrm{ha}^{-1}, 2=0.51-1.00 \mathrm{t} \mathrm{ha}^{-1}$, $3=1.01-1.50 \mathrm{t} \mathrm{ha}^{-1}, 4=1.51-2.00 \mathrm{t} \mathrm{ha}^{-1}, 5=>2.00 \mathrm{t} \mathrm{ha}^{-1}$. This is based on the idea that the control yield can serve as a proxy of the potential yield of the site (integrating the effect of soil, climate, pests, etc.) at a particular site and management conditions. For convenience, scores 1 and 2 defined low potential, 3 and 4 medium potential and scores above 4 defined high potential sites. Rainfall (long-term average of total annual) of sites was also classified as low $(<600 \mathrm{~mm})$, medium $(600-800 \mathrm{~mm})$ and high $(>800 \mathrm{~mm})$. Effects of factors such as rainfall and site condition were determined by a mixed model analysis that allowed for average correlation of observations from the same study.

The relative frequency of positive or negative effects was estimated for each practice using the cumulative probability distribution of $D$. This relative frequency was used as a proxy of the probability of obtaining a value of $D$ in any range as the two terms are not equivalent. Locations of results of individual studies were put into rainfall classes based on long-term annual rainfall averages.

Table 2

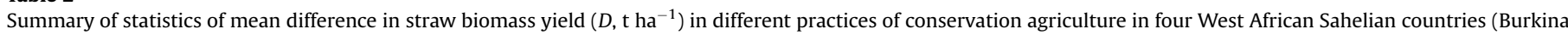
Faso, Mali, Niger and Senegal).

\begin{tabular}{|c|c|c|c|c|c|c|}
\hline & Parkland trees & Coppicing trees & Green manure & Mulching & Rotation-association & Soil \& water conservation \\
\hline Number of references $(N)$ & 9 & 9 & 5 & 7 & 4 & 8 \\
\hline Number of pairs $(k)$ & 26 & 79 & 28 & 53 & 169 & 86 \\
\hline Mean & 1.26 & 0.94 & 2.16 & 0.61 & 0.79 & 1.28 \\
\hline Upper quartile (75\%) & 2.15 & 1.78 & 3.07 & 1.43 & 1.39 & 2.07 \\
\hline Median (50\%) & -0.02 & 0.30 & 1.87 & 0.37 & 0.61 & 0.97 \\
\hline Lower quartile (25\%) & -0.24 & -0.28 & 1.25 & -0.19 & 0.20 & 0.36 \\
\hline Interquartile range & 2.39 & 2.06 & 1.82 & 1.62 & 1.19 & 1.71 \\
\hline$\%$ cases with $D \leq 0 \mathrm{t} \mathrm{ha}^{-1}$ & 53.9 & 36.7 & 3.6 & 35.9 & 17.2 & 10.5 \\
\hline$\%$ cases with $D \overline{0} .1-0.9 \mathrm{t} \mathrm{ha}^{-1}$ & 7.6 & 32.9 & 17.8 & 28.3 & 46.7 & 40.7 \\
\hline$\%$ cases with $D 1.0-2.0 \mathrm{t} \mathrm{ha}^{-1}$ & 11.6 & 8.9 & 35.7 & 20.7 & 26.6 & 23.2 \\
\hline$\%$ cases with $D>2.0 \mathrm{t} \mathrm{ha}^{-1}$ & 26.9 & 21.6 & 42.9 & 15.1 & 9.50 & 25.6 \\
\hline
\end{tabular}




\section{Results}

\subsection{Variability in yield response}

Summary statistics of $D$ are presented in Tables 1 and 2 for grain and straw biomass, respectively. Mean $D$ across all studies and crops were positive for each of the practices. This was true for both grain and biomass. The highest mean increase for grain was found with green manure legumes $\left(0.76 \mathrm{t} \mathrm{ha}^{-1}\right)$, while the lowest was with parkland trees $\left(0.02 \mathrm{t} \mathrm{ha}^{-1}\right)$. However, when separating $F$. albida from the rest of the species because of its reverse phenology, shedding leaves during the rainy season, mean difference in grain yield was $0.24 \mathrm{tha}^{-1}$ for $F$. albida compared to $-0.14 \mathrm{t} \mathrm{ha}^{-1}$ for the rest of the parkland species. In any case, the observed increases are modest. Average $D$ for biomass was higher than for grain and showed similar patterns with parklands having the lowest and green manure the highest means.

A large proportion of the cases recorded a reduction in grain yield $(D<0)$ in parklands (66\%) and coppicing trees (44\%) relative to the control (Table 1). Similarly, straw yields were lower than or equal to the control in over $50 \%$ of the cases in parklands, $37 \%$ of the cases in coppicing trees and $36 \%$ of the cases using mulching (Table 2). On the other hand, $D$ was greater than 0 in $75 \%$ of the cases with green manure legumes (Tables 1 and 2).
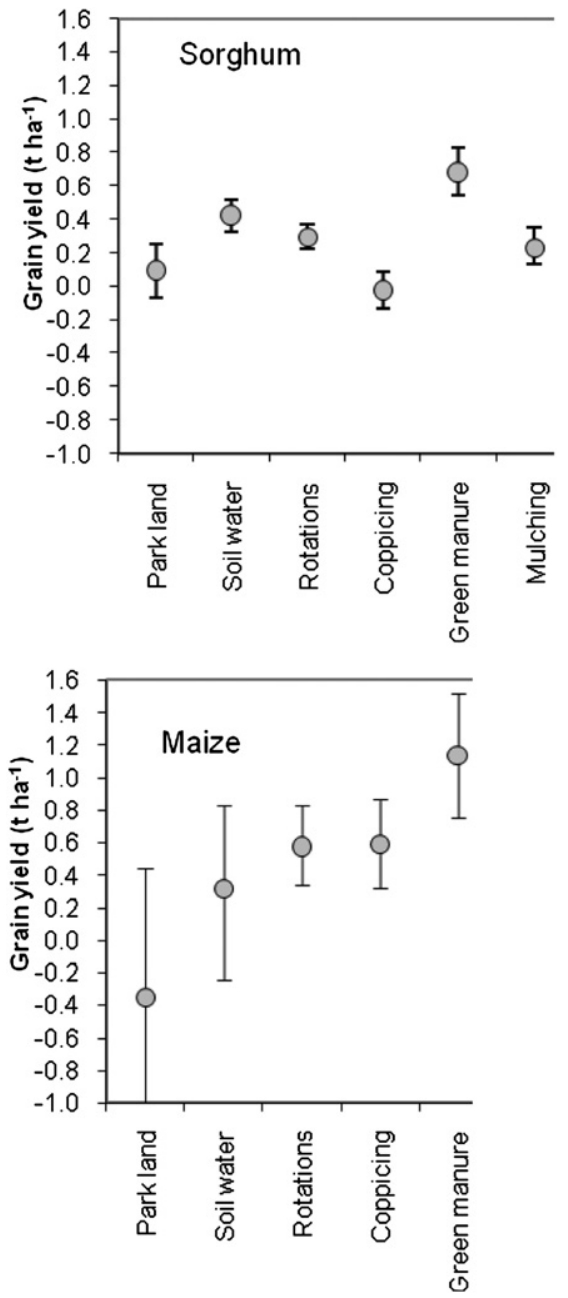

When crops were analyzed separately, mean yield differences varied significantly with site productivity in maize $(F=3.8$; $P=0.008)$, millet $(F=5.7 ; P<0.0001)$ and sorghum $(F=12.5$; $P<0.0001$ ). Gains in sorghum and maize yield relative to the control were higher with green manure legumes than most of the other practices (Fig. 1). In the case of millet, yield gains were higher with coppicing trees and mulching than with the other practices (Fig. 1).

\subsection{Factors affecting yield response}

\subsubsection{Site potential}

Differences in mean yield varied significantly with site productivity in maize $(F=7.5 ; P<0.0001)$, millet $(F=6.2 ; P<0.0001)$ and sorghum $(F=10.3 ; P<0.0001)$. Yield increase in each crop was higher on sites where the control plot achieved less than $2 \mathrm{t} \mathrm{ha}^{-1}$ (low to medium potential sites) than on high potential sites. On sites where the control yields were more than $2 \mathrm{t} \mathrm{ha}^{-1}$ (high potential site), yields of conservation agriculture practices were lower relative to the control except for maize for the crops (Fig. 2) and coppicing, rotations and soil and water conservation for the treatments (Fig. 3 ). Mean responses of maize are higher than millet and sorghum at all site potentials. Among the practices considered, green manure stands out as performing better on medium potential sites with

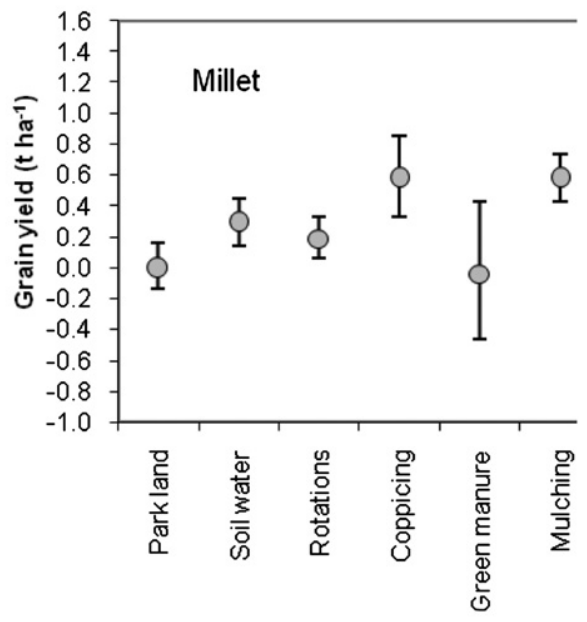

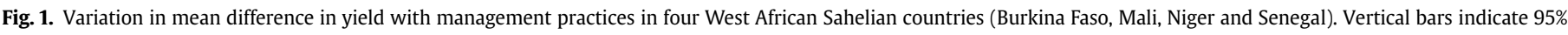
confidence bands. 


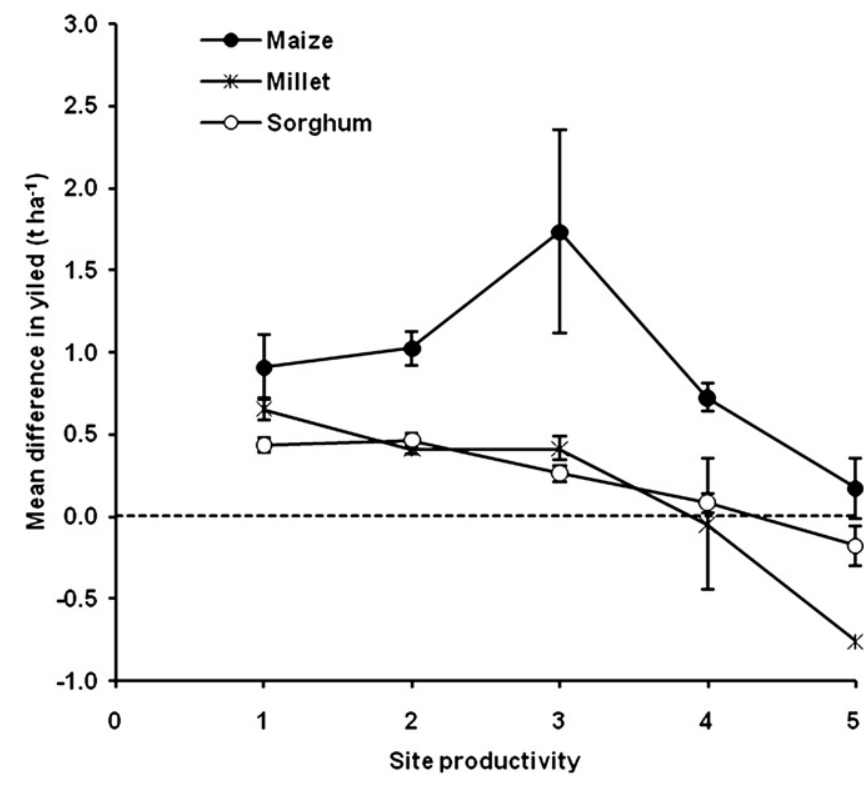

Fig. 2. Variation in mean difference in yield of cereal crops with site productivity in four West African Sahelian countries (Burkina Faso, Mali, Niger and Senegal). The broken line represents the point where the treatment and control yields are equal. 1 and 2 defined low potential, 3 and 4 medium potential and above 4 defined high potential sites. Vertical bars represent standard errors.

mean differences in yield for other practices being highest on low potential sites (Fig. 3).

\subsubsection{Rainfall effect}

Green manure legumes were not recorded in areas with rainfall $<601 \mathrm{~mm}$, and hence the small number of pairs (48) used for the analysis did not allow us to demonstrate green manure effects in the

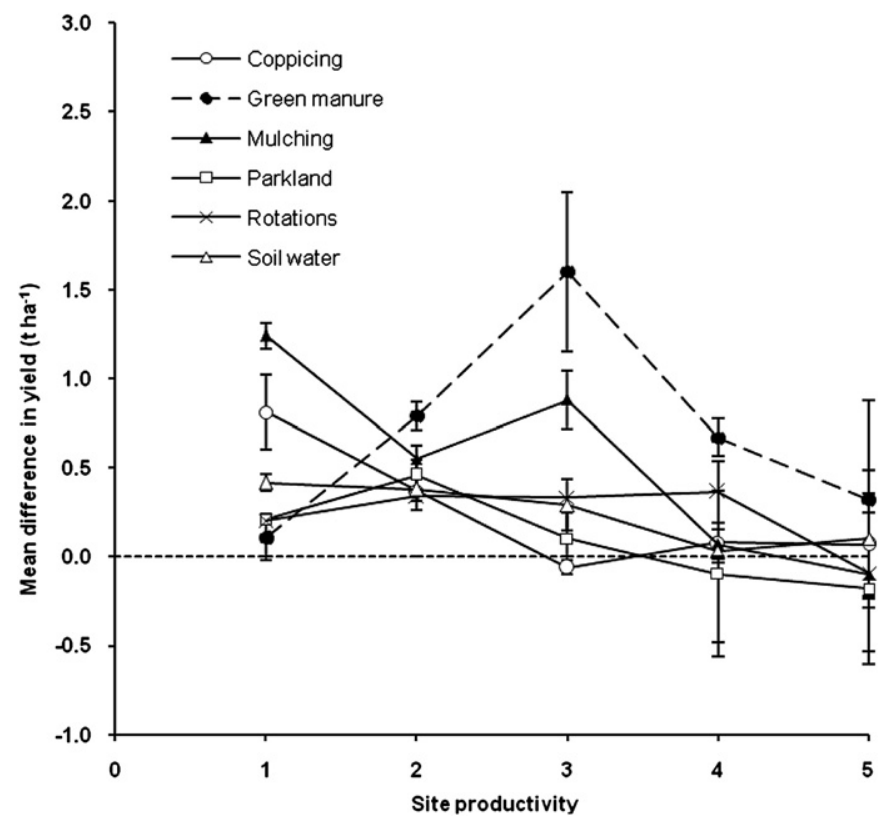

Fig. 3. Variation in mean difference in yield (across cereal crops) with soil and water conservation practices and site productivity in four West African Sahelian countries (Burkina Faso, Mali, Niger and Senegal). The broken line represents the point where the treatment and control yields are equal. 1 and 2 defined low potential, 3 and 4 medium potential and above 4 defined high potential sites. Vertical bars represent standard errors. drier areas. Lack of results in this rainfall zone may be due to evidence that these practices are inappropriate here, or simply that no one has tried them. Across cereals, differences in mean yield varied significantly with rainfall under coppicing legumes $(F=5.1$; $P=0.009)$, mulching $(F=7.1 ; P=0.001)$, parklands $(F=5.2$; $P=0.008)$, rotations $(F=23.7 ; P<0.0001)$ and soil and water conservation $(F=3.2 ; P=0.043)$. For coppicing trees, yield increases were generally more positive where annual average rainfall is $>800 \mathrm{~mm}$ or $<600 \mathrm{~mm}$. Mulching resulted in more positive $D$ where annual average rainfall is $<601 \mathrm{~mm}$, while the variability in response was very high when rainfall is $>800 \mathrm{~mm}$. Yield increases were lower relative to the control under parkland trees where annual average rainfall is $>800 \mathrm{~mm}$. Yield was reduced relative to the control with crop rotation-associations where annual average rainfall is $<800 \mathrm{~mm}$. Yield increases were higher with soil and water conservation practices where annual average rainfall is $<601 \mathrm{~mm}$, and lower where rainfall is $>800 \mathrm{~mm}$ (Table 3 ).

\subsection{Risk in yield response}

If we consider the cases in the analysis as a sample of what can happen when the conservation practice is introduced, then the potential risk to adopt a given practice can be estimated from the data. However, it is important to keep in mind that a slightly negative yield may not really constitute a risk for farmers while a slightly positive response may be just as risky, because it may not fully compensate for labour and/or capital expended in implementing the practice. Across crops, the probability of obtaining grain yields lower or equal to the control was $65 \%$ with parkland and $44 \%$ with coppicing legume trees. On the other hand yield risks were lower $(20 \%)$ with green manure and soil water conservation practices (Fig. 4a). Similarly, the risk of straw biomass lower or equal to the control was $54 \%$ for parkland and $40 \%$ for coppicing (Fig. 4b). On the hand, such risks were about $3 \%$ with green manure and $10 \%$ with soil and water conservation practices (Fig. $4 \mathrm{~b}$ ).

With any given practice, the probability of sorghum yield increase above $1.5 \mathrm{t} \mathrm{ha}^{-1}$ relative to the control was less than $10 \%$. There was $63 \%$ and $61 \%$ probability that sorghum grain yield will be lower or equal to the control when grown under parkland trees and with coppicing trees, respectively. On the other hand yield risks

Table 3

Effect of rainfall on cereal grain yield (across crops) response to conservation agriculture practices in four West African Sahelian countries (Burkina Faso, Mali, Niger and Senegal).

\begin{tabular}{llrrl}
\hline Practices (number of pairs) & Rainfall class & $D\left(\mathrm{t} \mathrm{ha}^{-1}\right)$ & \multicolumn{1}{c}{ LCI } & UCI \\
\hline Parkland (64) & $<601 \mathrm{~mm}$ & 0.36 & 0.06 & 0.65 \\
& $601-800 \mathrm{~mm}$ & 0.31 & 0.07 & 0.54 \\
& $>800 \mathrm{~mm}$ & -0.05 & -0.35 & 0.25 \\
Coppicing (89) & $<601 \mathrm{~mm}$ & 0.43 & 0.09 & 0.77 \\
& $601-800 \mathrm{~mm}$ & -0.29 & -0.75 & 0.17 \\
Green manure (48) & $>800 \mathrm{~mm}$ & 0.46 & 0.21 & 0.72 \\
& $<601 \mathrm{~mm}$ & - & - & - \\
& $601-800 \mathrm{~mm}$ & -0.03 & -1.0 & 0.95 \\
Mulching (89) & $>800 \mathrm{~mm}$ & 0.79 & 0.59 & 1.00 \\
& $<601 \mathrm{~mm}$ & 0.72 & 0.49 & 0.95 \\
Rotation/association (180) & $601-800 \mathrm{~mm}$ & 0.21 & 0.06 & 0.35 \\
& $>800 \mathrm{~mm}$ & 0.49 & -0.16 & 1.14 \\
& $<601 \mathrm{~mm}$ & -0.06 & -0.38 & 0.26 \\
Soil and water conservation (119) & $<601-800 \mathrm{~mm}$ & -0.31 & -0.65 & 0.03 \\
& $>800 \mathrm{~mm}$ & 0.14 & 0.15 & 0.42 \\
& $601-800 \mathrm{~mm}$ & 0.41 & 0.30 & 0.51 \\
& $>800 \mathrm{~mm}$ & -0.37 & 0.24 & 0.49 \\
& & -0.73 & 0.25 \\
\hline
\end{tabular}

The mean difference in yield $(D)$ and their lower and upper $95 \%$ confidence limits (LCI and UCI) are presented. The number of pairs reported here is excluding sites with missing altitude, rainfall or soil type data. 

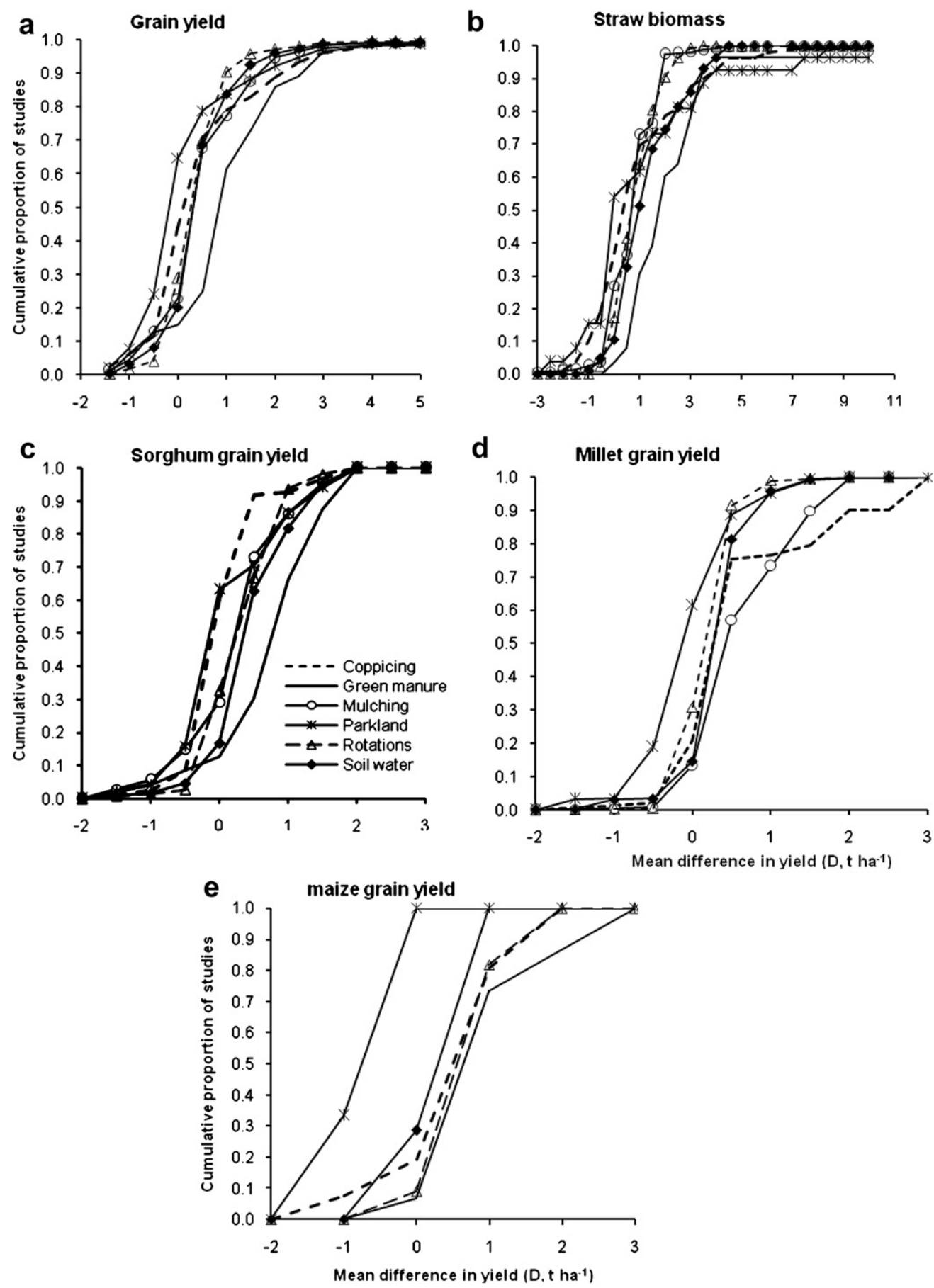

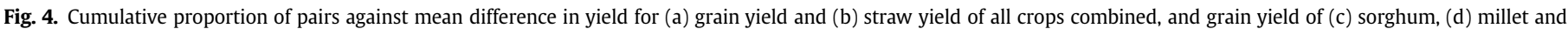
(e) maize in four West African Sahelian countries (Burkina Faso, Mali, Niger and Senegal). Legends for all figures are given in c.

were lower (20\%) when sorghum was associated with green manure legumes or soil water conservation practices (Fig. 4c).

As data points for millet grown with green manure were not sufficient, analyses were limited to the other practices. With any given practice, the probability of millet yield increase above $1.5 \mathrm{t} \mathrm{ha}^{-1}$ relative to the control was less than $10 \%$ except for coppicing legume species. There was $61 \%$ probability that millet grain yield will be lower or equal to the control when grown with parkland trees. On the other hand yield risks around 20\% was obtained when millet was grown with coppicing legumes, mulching or soil water conservation practices (Fig. 4d). The number of data points was small to do the analyses for maize. However, the limited data shows that yield risks were lower when maize was associated with green manure legumes or rotation/ association (Fig. 4e).

\section{Discussion}

Meta analyses such as this are powerful ways of pulling together quantitative information on common themes across 
disconnected studies, but suffer from some inherent challenges which must be born in mind when interpreting results. First, the contexts and details of each study vary, so there will inevitably be variation in the results. The aim in meta-analysis is to identify major consistent trends and not to explain every source of variation. But any source of variation across studies that can be identified is a valuable result. For example, for many studies the actual rainfall during the seasons included was not available, so we could only look at results in terms of long tern rainfall means of the study locations. Secondly, there are inherent biases in the process. The first is publication bias, due to the fact that more 'positive' results are published than negative results even though such hypothesis is not supported by the frequency of negative and positive results in the peer-reviewed publications (24\% negative and $76 \%$ positive) and grey literature (27\% negative and $73 \%$ positive) observed in the present synthesis. Nevertheless it should be kept in mind that grey literature is less accessible than published information and that may explain the statistics generated with our collected data. We have attempted to minimize that by searching for studies that did not reach formal publication, but there will certainly be others we did not identify that have been forgotten or deemed 'failures'.

Variability in $D$ was found to be high in all cases, and was therefore characterized and studied further. In all cases the median increases were less than the means and are perhaps a better indicator of 'typical impact' of each practice. Means being greater than medians is due to positive skewness in the distributions, sometimes taken as an indicator of publication bias.

Negative yield differences were observed in all practices for grain yield and dry matter with parkland showing the highest values (Tables 1 and 2). Such negative impact constitutes one of the reasons for the low adoption of practices such as improved fallows and cover crops that very often reduce the yields during the first year (Samba, 1997; Segda et al., 1998; Traoré et al., 1998; Bayala et al., 2003). In this study it was not possible to determine whether the $D$ measures are for short or long-term effects. However we know that if farmers do not see immediate tangible benefits they are less likely to adopt a technology. Short-term benefits are important because they determine to a large extent the attractiveness of CA to farmers (Giller et al., 2009). In most practices, except green manure, yield increases of $1 \mathrm{tha}$ or more over the control were recorded in less than $10 \%$ of the cases (Table 1). If the practice yields other direct tree products to farmers (such as fruit, animal fodder or fuelwood) then these might make the practice economically attractive, but again these are likely to be long-term benefits, with costs incurred until trees mature.

Green manure has the highest mean $D$ and lowest chance of negative values, particularly where land is of moderate fertility. Millet does not respond well to green manure, perhaps because local landraces used in most of the on-farm studies are less responsive to fertilization compared to improved varieties (Manyame, 2006). Another reason might be the "saturated fertility" effect as where soils are relatively fertile, the control is often as good as the treatment, with other factors, such as water, limiting the production. Millet has the highest average response to coppicing trees and mulching. These differences might reflect the differing environments in which millet and sorghum are grown, or differing contexts in which the technologies were evaluated. The results show that there is no single technology that works everywhere and under any circumstance leading to a need to define the socio-ecological niche of each technology (Knowler and Bradshaw, 2007; Giller et al., 2009). The best practice may also depend on the most appropriate combination of technological elements.
Despite the variability in $D$ response, the mean effects of various practices on crop yield are more positive than negative and the studies reviewed here have attributed this to various factors. The most common explanations were improvement in nutrient availability as a result of $\mathrm{N}$ input by biological $\mathrm{N}_{2}$ fixation (BNF), soil carbon building up, and improvement of soil physical properties due to increase soil organic matter and soil fauna activities (Mando and Stroosnijder, 1999; Bayala et al., 2006; Zougmoré et al., 2006; Sileshi et al., 2008; Sanou et al., 2010).

The results showed that the increase in yield of the three staple crops maize, millet and sorghum with conservation agriculture technologies is higher when the site is of poor or medium quality. On good soils, yields under conservation agriculture practices were lower relative to the control (Fig. 2). These results are in agreement with the findings of Buerkert and Stern (1995), Buerkert et al. (1995, 2000), and Sileshi et al. (2008). The poor soils gave higher increase in yield for each crop with all practices with mulching and coppicing performing the best (Fig. 3).

Yield increases in each crop were generally lower with parkland trees probably due to the competition between the trees and the annual crops as reported by many previous workers (Kater et al., 1992; Kessler, 1992; Bayala et al., 2002, 2008b). However, in parklands trees are very often fruit trees and the losses of crops are compensated for by fruit yield (Kessler, 1992). Trees can also be managed to reduce competition while generating wood and mulch material that can be used to improve crop production (Bayala et al., 2002, 2003, 2008a). The better crop performance with green manure legumes, coppicing trees and mulching is probably due to the organic materials added to the soil that trigger soil fauna activity, and improve soil physical and chemical properties (Tilander and Bonzi, 1997; Mando et al., 1999; Mando and Stroosnijder, 1999; Bayala et al., 2003; Masse et al., 2004; Bationo et al., 2007). Finally, it must be stressed that the evaluation of the yield in tree-based systems were done on total-area basis including the zone occupied by the trees themselves and that may lead to underestimating the absolute yield.

Coppicing and rotation/association appear to improve crop yields when the rainfall is higher than $800 \mathrm{~mm}$ whereas the opposite happened with parkland trees and soil and water conservation measures. This indicates that when water is the limiting factor, coppicing and rotation-association practices should be avoided as they will exacerbate the competition. Mulching performed better when the rainfall is less than $600 \mathrm{~mm}$ agreeing with the findings of some authors who worked on biomass transfer systems and showed large increases in crop and/or vegetation production where tree leaf litter was added (Mando et al., 1999; Jama et al., 2000). This is due to the fact that in drier environments improvement of soil physical properties by the mulch might be as important as the chemical properties because good physical properties enhance water holding capacity and efficient use of nutrients (Buerkert and Lamers, 1999; Bayala and Ouedraogo, 2008). Small size (48) of pairs used for the analysis did not allow us to estimate the potential effect for green manure on $D$ under different rainfall regimes. One can notice that this technology wasn't found in areas with less than $601 \mathrm{~mm}$ (Table 3) probably because the commonly used legumes could not be tested in drier areas. Since a small number of sites were available for green manure under these conditions one cannot conclude what is the limiting factor below $600 \mathrm{~mm}$ rainfall. It is probably water, as mulching becomes more effective under drier conditions. Still it is impossible to separate between the effect of water and soil fertility in this rainfall range. Therefore, further research is needed to establish the recommendation domain for green manure legumes in drylands that receive below $600 \mathrm{~mm}$. 
The probability of obtaining grain yields lower or equal to the control constitutes a risk to farmers if the performance of a technology on average, across a wide range of conditions, is used to give 'blanket' or standard recommendations. Accordingly, higher risks were associated with parklands and coppicing tree legume compared with green manure legumes (Fig. 2). The trend was the same even when analyzing crops separately (Fig. 4). High risk associated with the presence of trees is in accordance with the findings of previous workers who reported that sorghum and millet yields are generally substantially (30-60\%) reduced under parkland trees compared with the open field (Kater et al., 1992; Kessler, 1992; Boffa, 1995; Bayala et al., 2002). Such reduction in crop yield is attributed to competition for light, nutrients and water between the trees and the crops and light was found to be the most important factor in yield reduction (Kater et al., 1992; Kessler, 1992; Bayala et al., 2008b). Nevertheless, in most cases crop yield loss is compensated for by tree products (fruits, leaves, fuelwood, etc.) and other ecosystem services such as soil carbon building up (Kessler, 1992; Bayala et al., 2006; Takimoto et al., 2008). Tree-crop competition may be reduced by tree management practices such as pruning (Kessler, 1992; Bayala et al., 2002, 2008b) and by use of shade tolerant crops (Sanou, 2010; Sidibé, 2010; Pouliot et al., in press; Sanou et al., in press). Although in the short-term crop yields may be reduced due to competition, in the long-term favourable soil conditions (soil fertility) are provided by parklands. In addition, species like F. albida (data of the current study showed $0.24 \mathrm{t} \mathrm{ha}^{-1}$ mean difference in grain yield for $F$. albida against $-0.14 \mathrm{t} \mathrm{ha}^{-1}$ for the rest of the parkland species), $B$. aethiopum and $A$. digitata, which are included in the present study, can have positive effects on yields as they compete less with crops (Depommier et al., 1992; Louppe et al., 1996; Roupsard et al., 1996, 1999; Kho et al., 2001; Yaméogo, 2008; Sanou et al., in press). The risk results again point to the need for nuanced information that is relevant to the particular contexts and environments. An implication of this is that either researchers need to make much more progress in understanding when and where practices work (i.e. understanding practice $\times$ environment interaction) or farmers need to perform their own local experiments on multiple options. While the latter is desirable for social as well as technical reasons, the long-term nature of many of the practices makes it difficult in practice. These constraints are at least as important as the long-term nature of the trials. Hence researchers need to generate more information on the attributes of the species and the processes that are involved in making each of these practices beneficial or not, in order to make projections of best bets for any set of biophysical and farmer circumstances. This may be achieved through a combination of experimentation and process modelling.

The meta-analysis has adequately captured the diversity of environments in conservation agriculture practices in the drylands of the four studied countries and helped to identify the potential biophysical zones where studied technologies are the most suitable. Furthermore, species attributes could not be elucidated as well as the household socio-economic context in which each technology works or is adopted/adapted (Bayala et al., 2011). These conditions are important as there is no single technology that works everywhere and under any circumstance leading to a need to define the socio-ecological niche of each technology (Knowler and Bradshaw, 2007; Giller et al., 2009). For instance, low-cost techniques like farmer managed natural regeneration destined to become parklands may be easily adopted/adapted regardless of the wealth status of the farmer. However, there is a need for collective commitment to avoid the destruction of young seedlings by free roaming livestock as well as clear ownership of preserved trees through forest laws or local by-laws. There is also a need to find out more about when a parkland system will lead to cereal yield benefits, as that is inevitably an aim of farmers. The $65 \%$ risk of reducing grain yields found in this study needs reduction before a practice can be recommended. High-labour or resource-demanding techniques (like the zaii) need to be developed with the full participation of farmers and applied in conditions where people have no alternative but to reclaim their degraded lands due to high human and animal pressure, such as the Central Plateau of Burkina Faso, the Maradi/Zinder regions in Niger and the Dogon plateau in Mali. When the natural resources are still abundant, as in the south Sudanian zone, soil fertility replenishment issues are not always well perceived and that may explain why improved fallows tested for this zone were not adopted at a large scale. Any upscaling should be envisaged as a learning process using participatory research to better identify solutions for a range of socio-ecological conditions (Garrity et al., 2010).

\section{Conclusion and recommendations}

The results confirm that the practices studied, with the exception of parkland trees, do on average increase cereal yields, suggesting that building on and attempting to replicate the successes in using conservation agriculture techniques should be pursued. But the high level of variation in effects of these practices, including apparent reduction in cereal yields, has implications for the way this scaling up should be done. First, some of the variation can be explained by rainfall and site quality, allowing some level of site specificity in targeting interventions and making recommendations. The remaining high levels of variation require three approaches:

1. Ensuring projects/programmes and farmers are exposed to multiple options they can test and select from;

2. Promoting local experimentation to allow more nuanced and context-specific recommendations to be used and;

3. Continuing research aimed at understanding processes and principles, so that feasible interventions of particular contexts can be designed.

Together these will reduce the risks faced by farmers from the high levels that are inherent in the promotion of 'one size fits all' technologies.

The lack of unambiguous cereal yield benefits from the traditional practice of parkland trees is probably realistic. However, the trees are traditionally maintained in cropland for many purposes in addition to sustaining cereal yields. Our conclusion is that a more comprehensive analysis of the multiple benefits and services provided by parkland trees needs to be done. Current data is sparse, hence research is needed to increase understanding of them, their interactions and tradeoffs, and the way these are modified by specific contexts.

\section{Acknowledgements}

The authors acknowledge the financial support provided by the World Agroforestry Centre to prepare this review, and also thank anonymous reviewers for constructive comments. Participants to the validation workshop of this review held 8-10 March 2010 in Bamako, Mali are also acknowledged for their valuable contributions. Finally, we want to mention various stakeholders of the four Sahelian countries met during the review process, they are from national research institutes (IER, INERA, INRAN, ISRA), universities, ministries in charge of environment and agriculture, and NGOs. 
Appendix 1. List of publications included in the meta-analysis and conservation agriculture practices compared $(1=$ Parkland, $2=$ Coppicing, $3=$ Green manure, $4=$ Mulching, $5=$ Rotations and associations, and $6=$ Soil and water conservation).

\begin{tabular}{|c|c|c|c|}
\hline Author & Source & Country & Treatment \\
\hline Adam et al., 2006 & $\begin{array}{l}\text { Report Etudes Sahel. Centre Régional d'Enseignement Spécialisé en Agriculture (CRESA), } \\
\text { Niamey, Niger. }\end{array}$ & Niger & 6 \\
\hline Ambouta and Amadou, 2000 & Annales de l’Université Abdou Moumouni de Niamay, Hors Série: 97-105. & Niger & 4,6 \\
\hline Ambouta et al., 2000 & Book; In: Floret C., Pontanier R. (Eds) La jachère en Afrique tropicale. pp. 751-759. & Niger & 4,6 \\
\hline Bado et al., 2006a & $\begin{array}{l}\text { Proceedings series on Management practices for improving sustainable crop production } \\
\text { in tropical acid soils. International Atomic Energy Agency, Vienna Austria, pp. 47-63. }\end{array}$ & Burkina Faso & 4,5 \\
\hline Bado et al., 2006b & Biology and Fertility of Soils 43 (2): 171-176. & Burkina Faso & 5 \\
\hline Bagayoko et al., 2000 & Plant and Soil 218: 103-116. & $\mathrm{BF}$ and Niger & 5 \\
\hline Barro and Zougmore, 2005 & Cahiers Agricultures 14: 549-559. & Burkina Faso & 6 \\
\hline Bationo et al., 2007 & Agricultural Systems 94: 13-25. & Niger & 4 \\
\hline Bayala, 2002 & PhD thesis, University of Wales, Bangor, UK. & Burkina Faso & 1 \\
\hline Bayala et al., 2003 & Arid Land Research and Management 17: 283-296. & Burkina Faso & 4 \\
\hline Belemviré et al., 2008 & $\begin{array}{l}\text { Report Rapport de synthèse Etude sahel Burkina Faso. Ouagadougou, Burkina Faso: } \\
\text { Comité Permanent Inter Etats pour la Lutte contre la Sécheresse au Sahel, } 94 \text { p. }\end{array}$ & Burkina Faso & 6 \\
\hline Boffa et al., 2000 & Agroforestry Systems 49: $153-175$. & Burkina Faso & 1 \\
\hline Buerkert and Lamers, 1999 & Plant and Soil 215: 239-253. & Niger & 4 \\
\hline Charreau and Vidal, 1965 & Agronomie Tropicale 6-7: 660-686. & Senegal & 1 \\
\hline Coulibaly, 2002 & $\begin{array}{l}\text { Mémoire de fin d'études d'Ingénieur de l'Institut Polytechnique Rural de Formation } \\
\text { et de Recherche Appliquée IPR/IFRA de Katibougou, Mali, } 43 \text { p. }\end{array}$ & Mali & 3 \\
\hline Coulibaly et al., 2000 & African Crop Science Journal 8(4): 411-418. & Mali & 4 \\
\hline Dembele, 2006 & $\begin{array}{l}\text { Mémoire de fin d'études d'Ingénieur de l'Institut Polytechnique Rural de Formation } \\
\text { et de Recherche Appliquée IPR/IFRA de Katibougou, Mali, } 69 \text { p. }\end{array}$ & Mali & 2 \\
\hline Dembele, 1998 & $\begin{array}{l}\text { Mémoire de fin d'études d'Ingénieur de l'Institut Polytechnique Rural de Formation } \\
\text { et de Recherche Appliquée IPR/IFRA de Katibougou, Mali, } 93 \text { p. }\end{array}$ & Mali & 3 \\
\hline Depommier et al., 1992 & $\begin{array}{l}\text { Proceedings of a workshop, 22-26 April 1991, Niamey, Niger. ICRISAT Patancheru, } \\
\text { India: International Crops Research Institute for Semi-Arid Tropics (ICRISAT) } \\
\text { and International Centre for Research in Agroforestry. Kenya, pp. 111-115. }\end{array}$ & Burkina Faso & 1 \\
\hline Diatta et al., 2001 & Sécheresse 12 (1): 15-24. & Senegal & 6 \\
\hline Dibloni et al., 1999 & $\begin{array}{l}\text { Rapport technique d'activités. Programme collaboratif ICRAF-SALWA, INERA-DPF, } \\
\text { Ouagadougou, Burkina Faso, } 51 \text { p. }\end{array}$ & Burkina Faso & 1 \\
\hline Doumbia, 2000 & $\begin{array}{l}\text { Mémoire de fin d'études d'Ingénieur de l'Institut Polytechnique Rural de Formation } \\
\text { et de Recherche Appliquée IPR/IFRA de Katibougou, Mali, } 31 \text { p. }\end{array}$ & Mali & 2,3 \\
\hline Doumbia et al., 2001 & Drylands Research Report No. 14. & Mali & 6 \\
\hline Fatondji et al., 2011 & $\begin{array}{l}\text { Fatondji D, Pasternak D, Nikiema A, Senbeto D, Woltering L, Njeunga J, Abdoussalam S (2011) } \\
\text { Integrated agricultural production system management - The dryland Eco-Farm, a potential } \\
\text { solution to the main constraints of Africa's rain-fed agriculture. In: Bationo A, Waswa B, Okeya } \\
\text { JM, Mina F, Kihara JM (Eds.). Innovations as Key to the Green Revolution in Africa. }\end{array}$ & Niger & 2 \\
\hline Gigou et al., 2006 & Cahier Agricultures 15 (1): 116-122. & Mali & 6 \\
\hline Harouna, 2002 & $\begin{array}{l}\text { Mémoire de diplôme d'Ingénieur des Techniques Agricoles. Université Abdou Moumouni, } \\
\text { Faculté d'Agronomie, Niamey, Niger, } 59 \text { p. }\end{array}$ & Niger & 4 \\
\hline INERA/RSP Centre, 1996 & Annual Report, INERA, Burkina Faso. & Burkina Faso & 4,6 \\
\hline Kaya and Nair, 2001 & Agroforestry Systems 52 (1): 1-11. & Mali & 2,3 \\
\hline Kho et al., 2001 & Agroforestry Systems 52 (3): 219-238. & Niger & 1 \\
\hline Kone, 2007 & $\begin{array}{l}\text { Mémoire de fin d'études d'Ingénieur de l'Institut Polytechnique Rural de Formation } \\
\text { et de Recherche Appliquée IPR/IFRA de Katibougou, Mali, } 59 \text { p. }\end{array}$ & Burkina Faso & 5,6 \\
\hline Kone, 2008 & $\begin{array}{l}\text { Mémoire de fin d'études d'Ingénieur de l'Institut Polytechnique Rural de Formation } \\
\text { et de Recherche Appliquée IPR/IFRA de Katibougou, Mali, } 56 \text { p. }\end{array}$ & Mali & 2 \\
\hline Kouyaté et al., 2000 & Plant and Soil $225(1-2): 141-151$. & Mali & 5 \\
\hline Louppe et al., 1996 & Cahiers Scientifiques 12: 123-139. & Senegal & 1 \\
\hline Maiga, 1987 & Rapport de stage. IRBET/CNRST, Ouagadougou, Burkina Faso. 86 p. & Burkina Faso & 1 \\
\hline Mando et al., 2001 & $\begin{array}{l}\text { In: Floret C., Pontanier R. (Eds) La jachère en Afrique Tropicale, vol. 2: de la jachère naturelle à } \\
\text { la jachère améliorée, le point des connaissances, UNESCO, Paris, France, pp. } 311-339 \text {. }\end{array}$ & Burkina Faso, Niger & 4,6 \\
\hline Masse et al., 2004 & Soil Use and Management 20 (1): 92-95. & Senegal & 2,3 \\
\hline Mbaikoubou, 2005 & $\begin{array}{l}\text { Mémoire de fin d'études d'Ingénieur de l'Institut Polytechnique Rural de Formation } \\
\text { et de Recherche Appliquée IPR/IFRA de Katibougou, Mali, } 61 \text { p. }\end{array}$ & Mali & 3 \\
\hline Ndiaye et al., 2000 & Arid Soil Research and Rehabilitation 14 (4): 317-327. & Senegal & 2 \\
\hline Oliver et al., 1996 & Cahiers Scientifiques $\mathrm{N}^{\circ} 12$, Montpellier, pp 141-152. & Burkina Faso & 1 \\
\hline Ouédraogo et al., 2007 & Soil \& Tillage Research 94 (1): 64-74. & Burkina Faso & 4 \\
\hline Ouédraogo, 2008 & $\begin{array}{l}\text { Book, In Bationo A., Tabo R., Waswa B.S., Okeyo J., Fosu M., Kabore S.: Synthesis of soil, } \\
\text { water and nutrient management research in the Volta Basin, pp. 43-66. }\end{array}$ & Burkina Faso & 6 \\
\hline Pouliot, 2007 & MSc thesis, University of Copenhagen, Denmark. & Burkina Faso & 1 \\
\hline Roose and Barthès, 2001 & Nutrient Cycling in Agroecosystems $61(1-2)$ : 159-170. & Burkina Faso & 6 \\
\hline Roose et al., 1999 & Soil Research and Rehabilitation 13: 343-335. & Burkina Faso & 6 \\
\hline Sanogo, 1997 & $\begin{array}{l}\text { Mémoire de fin d'études d'Ingénieur de l'Institut Polytechnique de Formation et de } \\
\text { Recherche Appliquée IPR/IFRA de Katibougou, Mali, } 44 \text { p. }\end{array}$ & Mali & 2 \\
\hline Sanou, 2010 & $\mathrm{PhD}$ thesis, University of Bangor, UK. & Burkina Faso & 1 \\
\hline Sidibé, 2010 & PhD thesis, University of Bangor, UK. & Mali & 1 \\
\hline Tangara, 1996 & $\begin{array}{l}\text { Mémoire de fin d'études de Technicien Supérieur de l'Institut Polytechnique Rural de } \\
\text { Formation et de Recherche Appliquée IPR/IFRA de Katibougou, Mali, } 28 \text { p. }\end{array}$ & Mali & 2 \\
\hline Thienou, 2005 & $\begin{array}{l}\text { Mémoire de fin d'études d'Ingénieur de l'Institut Polytechnique Rural de Formation et de } \\
\text { Recherche Appliquée IPR/IFRA de Katibougou, Mali, } 60 \text { p. }\end{array}$ & Mali & 2 \\
\hline Tilander, 1993 & Agroforestry Systems 24(3): 277-293. & Burkina Faso & 4 \\
\hline
\end{tabular}


(continued)

\begin{tabular}{|c|c|c|c|}
\hline Author & Source & Country & Treatment \\
\hline Tilander and Bonzi, 1997 & Plant and Soil 197: 219-232. & Burkina Faso & 4 \\
\hline Togo Idrissa & $\begin{array}{l}\text { Mémoire de fin d'études d'Ingénieur de l'Institut Polytechnique Rural de Formation et de } \\
\text { Recherche Appliquée IPR/IFRA de Katibougou, Mali, } 44 \text { p. }\end{array}$ & Mali & 2 \\
\hline Traoré and Zougmoré, 2008 & $\begin{array}{l}\text { Report, Conservation agriculture in Africa: state of the art in Burkina Faso, INERA, } \\
\text { Burkina Faso, } 14 \text { p. }\end{array}$ & Burkina Faso & 3,5 \\
\hline Wilson et al., 1998 & Experimental Agriculture 35: 85-98. & Burkina Faso & 1 \\
\hline Yaméogo, 2008 & $\mathrm{PhD}$ thesis, University of Ouagadougou, Burkina Faso. & Burkina Faso & 1 \\
\hline Yossi et al., 2002 & Report, Rapport final. IER Sikasso, Mali, 27 p. & Mali & $1,2,3$ \\
\hline Zerome, 2005 & $\begin{array}{l}\text { Mémoire de fin d'études d'Ingénieur de l'Institut Polytechnique Rural de Formation } \\
\text { et de Recherche Appliquée IPR/IFRA de Katibougou, Mali, } 46 \text { p. }\end{array}$ & Mali & 3 \\
\hline Zomboudré et al., 2005 & Biotechnologie, Agrononmie, Société et Environnement 9: 75-85. & Burkina Faso & 1 \\
\hline Zougmoré et al., 2000 & Arid Soil Research and Rehabilitation 14: 329-342. & Burkina Faso & 6 \\
\hline Zougmoré et al., 2003 & Soil Tillage Research 71: 143-149. & Burkina Faso & 6 \\
\hline Zougmoré et al., 2004 & Field Crops Research 90 (2-3): 235-244. & Burkina Faso & 6 \\
\hline
\end{tabular}

\section{References}

ACT, 2008. Linking production, livelihoods and conservation. In: Proceedings of the Third World Congress on Conservation Agriculture, 3-7 October, 2005, Nairobi. African Conservation Tillage Network, Nairobi, Kenya.

Adam, T., Reij, C., Abdoulaye, T., Larwanou, M., Tappan, G., Yamba, B., 2006. Impacts des investissements dans la gestion des ressources naturelles (GRN) au Niger: Rapport the synthèse. Centre Régional d'Enseignement Spécialisé en Agriculture (CRESA), Niamey, Niger.

Ambouta, J.M.K., Amadou, I., 2000. Effets de techniques traditionnelles de récupération des terres sur la productivité de plages dénudées de jachères au sahel. In: Annales de l'Université Abdou Moumouni de Niamay, Hors Série, pp. 97-105.

Bado, B.V., Bationo, A., Cescas, M.P., 2006a. Assessment of cowpea and groundnut contributions to soil fertility and succeeding sorghum yields in the Guinean savannah zone of Burkina Faso (West Africa). Biology and Fertility of Soils 43 (2), 171-176.

Bado, B.V., Bationo, A., Lompo, F., Cescas, M.P., Sedogo, M.P., 2006b. Long-term effects of cropping systems on crop yields, soil properties and nitrogen recoveries in the Guinean and Soudanian savannah zone of Burkina Faso (west Africa). In: Proceedings Series on Management Practices for Improving Sustainable Crop Production in Tropical Acid Soils. International Atomic Energy Agency, Vienna Austria, pp. 47-63.

Bagayoko, M., Buerkert, A., Lung, G., Bationo, A., Römheld, V., 2000. Cereal/legume rotation on cereal growth in Sudano-Sahelian West Africa: soil mineral nitrogen, mycorrhizae and nematodes. Plant and Soil 218, 103-116.

Barro, A., Zougmore, R., 2005. Utilisation du mucuna et du zaï mécanique dans la réhabilitation des sols et l'amélioration des revenus des exploitations agricoles du Burkina Faso. In: FAO (Ed.), Regards sur l'agriculture de conservation en Afrique de l'Ouest et du centre et ses perspectives, Contribution au 3ème Congrès mondial d'agriculture de conservation, Nairobi, octobre 2005. FAO, Rome, pp. 27-37.

Bationo, A., Traore, Z., Kimetu, J., Bagayoko, M., Kihara, J., Bado, V., Lompo, M., Tabo, R Koala, S., 2003. Cropping Systems in the Sudano-Sahelian Zone: Implications on Soil Fertility Management From: http://www.syngentafoundation.org/db/1/432.pdf.

Bationo, A., Hartemink, A., Lungu, O., Naimi, M., Okoth, P., Smaling, E. Thiombiano, L., 2006. African Soils: Their Productivity and Profitability of Fertilizer Use. Background Paper Presented for the African Fertilizer Summit 9-13th June 2006. Abuja, Nigeria.

Bationo, A., Kihara, J., Vanlauwe, B., Waswa, B., Kimetu, J., 2007. Soil organic carbon dynamics, functions and management in West African agro-ecosystems. Agroforestry Systems 94, 13-25.

Bayala, J., Ouedraogo, S.J., 2008. Agroforestry and soil fertility maintenance. In: Bationo, A., Tabo, R., Waswa, B.S., Okeyo, J., Fosu, M., Kabore, S. (Eds.), Synthesis of Soil, Water and Nutrient Management Research in the Volta Basin. Ecomedia, Nairobi, Kenya, pp. 43-66.

Bayala, J., Teklehaimanot, Z., Ouedraogo, S.J., 2002. Millet production under pruned tree crowns in a parkland system in Burkina Faso. Agroforestry Systems 54, 203-214.

Bayala, J., Mando, A., Ouedraogo, S.J., Teklehaimanot, Z., 2003. Managing Parkia biglobosa and Vitellaria paradoxa prunings for crop production and improved soil properties in the Sub-Sudanian zone of Burkina Faso. Arid Land Research and Management 17, 283-296.

Bayala, J., Balesdent, J., Marol, C., Zapata, F., Teklehaimanot, Z, Ouedraogo, S.J., 2006. Relative contribution of trees and crops to soil carbon content in a parkland system in Burkina Faso using variations in natural ${ }^{13} \mathrm{C}$ abundance. Nutrient Cycling in Agroecosystems 76, 193-201.

Bayala, J., Ouedraogo, S.J., Teklehaimanot, Z., 2008a. Rejuvenating indigenous trees in agroforestry parkland systems for better fruit production using crown pruning. Agroforestry Systems 72, 187-194.

Bayala, J., van Noordwijk, M., Lusiana, B., Kasanah, N., Teklehaimanot, Z., Ouedraogo, S.J., 2008b. Separating the tree-soil-crop interactions in agroforestry parkland systems in Saponé (Burkina Faso) using WaNuLCAS. Advances in Agroforestry 4, 296-308.
Bayala, J., Kalinganire, A., Tchoundjeu, Z., Sinclair, F., Garrity, D., 2011. Conservation agriculture with trees in the West African Sahel - a review. ICRAF Occasional Paper No. 14. World Agroforestry Centre, Nairobi.

Belemviré, A., Maïga, M., Sawadogo, H., Savadogo, M., Ouedraogo, S., 2008. Evaluation des impacts biophysiques et socio-économiques des investissements dans les actions de gestion des ressources naturelles au Nord du Plateau Central du Burkina Faso. Rapport de synthèse Etude sahel Burkina Faso. Comité Permanent Inter Etats pour la Lutte contre la Sécheresse au Sahel, Ouagadougou, Burkina Faso.

Bengaly, S., 2008. Etude sur les savoirs local et moderne en matière de gestion de la fertilité du sol: cas du village de Samine, région de Ségou. Mémoire de fin d'études d'Ingénieur de l'Institut Polytechnique Rural de Formation et de Recherche Appliquée IPR/IFRA de Katibougou, Mali.

Boffa, J.M., 1995. Productivity and management of agroforestry parklands in the Sudan zone of Burkina Faso, West Africa. PhD. Dissertation, Perdue University, West Lafayette, Indiana, USA.

Boffa, J.M., Taonda, S.J.B., Dickey, J.B., Knudson, D.M., 2000. Field-scale influence of karité (Vitellaria paradoxa) on sorghum production in the Sudan zone of Burkina Faso. Agroforestry Systems 49, 153-175.

Bonkoungou, G.E., Djimde, M., Ayuk, E.T., Zoungrana, I., Tchoundjeu, Z., 1998. Taking Stock of Agroforestry in the Sahel-harvesting Results for the Future. ICRAF, Nairobi, Kenya.

Buerkert, A., Lamers, J.P.A., 1999. Soil erosion and deposition effects on surface characteristics and pearl millet growth in the West African Sahel. Plant and Soil $215,239-253$.

Buerkert, A., Stern, R.D., 1995. Crop residue and P application affect the spatial variability of non-destructively measured millet growth in the Sahel. Experimental Agriculture 31, 429-449.

Buerkert, A., Stern, R.D., Marschner, H., 1995. Post stratification clarifies treatment effects on millet growth in the Sahel. Agronomy Journal 87, 752-761.

Buerkert, A., Bationo, A., Dossa, K., 2000. Mechanisms of residue mulch-induced cereal growth increases in West Africa. Soil Science Society of America Journal 64, 346-358.

Coghlan, A., 2006. More crops for Africa as trees reclaim desert. New Scientist 192 (2573), 11.

Coulibaly, A., Bagayoko, M., Traore, S., Mason, S.C., 2000. Effect of crop residue management and cropping system on pearl millet and cowpea yield. African Crop Science Journal 8 (4), 411-418.

Dai, A., Lamb, P.J., Trenberth, K.E., Hulme, K., Jones, P.D., Xie, P., 2004. The recent Sahel drought is real. International Journal of Climatology 24, 1323-1331.

Depommier, D., Janodet, E., Roupsard, O., 1992. Faidherbia albida parks and their influence on soils and crops at Watimona, Burkina Faso. In: Vandenbeldt, R.J. (Ed.), Faidherbia Albida in the West African Semi-arid Tropics. Proceedings of a Workshop, 22-26 April 1991, Niamey, Niger. ICRISAT Patancheru, India: International Crops Research Institute for Semi-Arid Tropics (ICRISAT) and International Centre for Research in Agroforestry, Kenya, pp. 111-115.

Diatta, M., Faye, E., Grouzis, M., Perez, P., 2001. Importance de la haie vive isohypse sur la gestion de l'eau du sol et le rendement des cultures dans un bassin versant de Thyssé-Kaymor, Sénégal. Secheresse 12 (1), 15-24.

Dibloni, O.T., Ouédraogo, S.J., Koala, J., 1999. Rapport technique d'activités. Programme collaboratif ICRAF-SALWA. INERA-DPF, Ouagadougou, Burkina Faso.

Doumbia, M.D., Berthé, A., Aune, J.D., 2001. Integrated Plant Nutrition Management (IPNM): Practical Testing of Technologies with Farmers Groups. Drylands Research Report No. 14.

Drechsel, P., Steiner, K.G., Hagedorn, F., 1996. A review on the potential of improved fallows and green manure in Rwanda. Agroforestry Systems 33, 109-136.

Food and Agriculture Organization (FAO), 2004. Rehabilitation of degraded lands in Sub-Saharan Africa: lessons from case studies. In: Workshop on Strengthening Regional Action - Implementation of the IPF/IFF Proposals for Action in Africa. FAO, Accra, Ghana.

Food and Agriculture Organization (FAO), 2009. Enhancing Crop-livestock Systems in Conservation Agriculture for Sustainable Production Intensification: A Farmer Discovery Process Going to Scale in Burkina Faso. In: Integrated Crop Management, vol. 7 Rome, Italy. 
Fatondji, D., Pasternak, D., Nikiema, A., Senbeto, D., Woltering, L., Ndjeunga, J., Abdoussalam, J., 2011. Integrated agricultural production system - the dryland ecofarm, a potential solution to the main constraints of Africa's rain-fed agriculture. In: Bationo, A., Waswa, B., Okeyo, J.M., Maina, F., Kihara, J.M. (Eds.), Innovations as Key to the Green Revolution in Africa: Exploring the Scientific Facts, pp. 1115-1123.

Garrity, D.P., Akinnifesi, F.K., Ajayi, O.C., Weldesemayat, S.G., Mowo, J.G., Kalinganire, A., Larwanou, M., Bayala, J., 2010. Evergreen agriculture: a robust approach to sustainable food security in Africa. Food Security 2, 197-214.

Gelman, A., Carlin, J.B., Stern, H.S., Rubin, D.B., 1995. Bayesian Data Analysis. Chapman and Hall, London, UK.

Gigou, J., Traoré, K., Giraudy, F., Coulibaly, H., Sogoba, B., Doumbia, M., 2006. Aménagement paysan des terres et réduction du ruissellement dans les savanes africaines. Secheresse 15, 116-122.

Gijsbers, H.J.M., Kessler, J.J., Knevel, M.K., 1994. Dynamics and natural regeneration of woody species in farmed parklands in the Sahel region (Province of Passore, Burkina Faso). Forest Ecology and Management 64, 1-12.

Giller, K.E., Witter, E., Corbeels, M., Tittonelle, P., 2009. Conservation agriculture and smallholder farming in Africa: the heretics' view. Field Crops Research 114, $23-34$.

Guichard, F., Frappart, F., Hiernaux, P., Kergoat, L., Mougin, E., Arjounin, M., Koité, M. Lebel, T., Bock, O., Meynadier, R., 2010. A multi-scale analysis of in-situ precipitation data across the Sahelian Gourma. Geophysical Research Abstracts 12 EGU2010-9271-2.

Hassan, R.M., Scholes, R., Ash, N., 2005. Ecosystems and Human Well-being: Current State and Trends. Millennium Ecosystem Assessment. Island Press.

Hauser, S., Nolte, C., Carsky, R.J., 2006. What role can planted fallows play in the humid and sub-humid zone of West and Central Africa? Nutrient Cycling in Agroecosystems 76, 297-318.

Heinrigs, P., Perret, C., 2009. Vulnerability in the Sahelian zone. In: Regional Atlas on West Africa. OECD, Sahel and West Africa Club, Economic Community of West African States.

Jama, B., Palm, C.A., Buresh, R.J., Niang, A., Gahengo,.C, Nziguheba, G., Amadalo, B., 2000. Tithonia diversifolia as a green manure for soil fertility improvement in western Kenya: a review. Agroforestry Systems 49, 201-221.

Kandji, S.T., Verchot, L., Mackensen, J., 2006. Climate Change and Variability in the Sahel Region: Impacts and Adaptation Strategies in the Agricultural Sector. ICRAF/UNEP, Nairobi, Kenya.

Kater, L.J.M., Kante, S., Budelman, A., 1992. Karité (Vitellaria paradoxa) and néré (Parkia biglobosa) associated with crops in south Mali. Agroforestry Systems 18, 89-105.

Kessler, J.J., 1992. The influence of karité (Vitellaria paradoxa) and néré (Parkia biglobosa) trees on sorghum production in Burkina Faso. Agroforestry Systems 17, 97-118.

Kho, R.M., Yacouba, B., Yayé, M., Katkoré, B., Moussa, A., Iktam, A., Mayaki, A., 2001. Separating the effects of trees on crops: the case of Faidherbia albida and millet in Niger. Agroforestry Systems 52 (3), 219-238.

Kirmse, R.D., Norton, B.E., 1984. The potential of Acacia albida for desertification control and increased productivity in Chad. Biological Conservation 29, 121-141.

Knowler, D., Bradshaw, B., 2007. Farmers' adoption of conservation agriculture: a review and synthesis of recent research. Food Policy 32, 25-48.

Kouyaté, Z., Franzluebbers, K., Juo, A.S.R., Hossner, L., 2000. Tillage, crop residue, legume rotation, and green manure effects on sorghum and millet yields in the semiarid tropics of Mali. Plant and Soil 225, 141-151.

Louppe, D., N'Dour, B., Samba, S.A.N., 1996. Influence de Faidherbia albida sur l'arachide et le mil au Sénégal. In: Peltier, R. (Ed.), Les parcs à Faidherbia. Cahiers Scientifiques, vol. 12, pp. 123-193.

Mando, A., Stroosnijder, L., 1999. The biological and physical role of mulch in the rehabilitation of crusted soil in the Sahel. Soil Use Manage 15 (2) 123-127.

Mando, A., Brussard, L., Stroosnijder, L., 1999. Termite- and mulch-mediated rehabilitation of vegetation on crusted soil in West Africa. Restoration Ecology 7, 33-41.

Manyame, C., 2006. On-farm yield and water use response of pearl millet to different management practices in Niger. PhD Dissertation, Texas A \& M University, USA.

Maranz, S., 2009. Tree mortality in the African Sahel indicates an anthropogenic ecosystem displaced by climate change. Journal of Biogeography 36, 1181-1193.

Masse, D., Manay, R.J., Diatta, M., Pontanier, R., Chotte, J.L., 2004. Soil properties and plant production after short-term fallows in Senegal. Soil Use and Management 20, 92-95.

Mortimore, M., Turner, B., 2005. Does the Sahelian smallholder's management of woodland, farm trees, rangeland support the hypothesis of human-induced desertification? Journal of Arid Environments 63, 567-595.

Ndiaye, M., Ganry, F., Oliver, R., 2000. Alley cropping of maize and Gliricidia sepium in the Sudanese Sahel region: some technical feasibility aspects. Arid Soil Research and Rehabilitation 14, 317-327.

Oliver, R., Depommier, D., Janodet, E., 1996. Influence de Faidherbia albida sur le sol et le sorgho: Observations dans le parc de Watinoma au Burkina Faso. In: Peltier, R. (Ed.), Les parcs à Faidherbia. Cahiers Scientifiques, vol. 12. CIRADForêt, Montpellier, pp. 141-152.

Ouédraogo, E., Stroosnijder, L., Mando, A., Brussaard, L., Zougmore, R., 2007. Agroecological analysis and economic benefit of organic resources and fertiliser in till and no-till sorghum production after a 6-year fallow in semi-arid West Africa. Nutrient Cycling in Agroecosystems 77, 245-256

Pouliot, M., Bayala, J., Ræbild, A., in press. Testing the shade tolerance of selected crops under Parkia biglobosa (Jacq.) Benth. in an agroforestry parkland in Burkina Faso, West Africa. Agroforestry Systems 71 (3). doi:10.1007/s10457-011-9411-6.
Rao, M.R., Nair, P.K.R., Ong, C.K., 1998. Biophysical interactions in tropical agroforestry systems. Agroforestry Systems 38, 3-50.

Reij, C.P., Smaling, E.M.A., 2008. Analyzing successes in agriculture and land management in Sub-Saharan Africa: is macro-level gloom obscuring positive micro-level change? Land Use Policy 25, 410-420.

Reij, C., Tappan, G., Belemvire, A., 2005. Changing land management practices and vegetation on the Central Plateau of Burkina Faso (1968-2002). Journal of Arid Environments 63, 642-659.

Reij, C., Tappan, G., Smale, M., 2009. Re-greening the Sahel: farmer-led innovation in Burkina Faso and Niger. In: Agroenvironmental Transformation in the Sahel: Another kind of "Green Revolution" IFPRI Discussion Paper. International Food Policy Research Institute, Washington, D.C.

Rockström, J., Kaumbutho, P., Mwalley, J., Nzabi, A.W., Temesgen, M., Mawenya, L. Barron, J., Mutua, J., Damgaard-Larsen, S., 2009. Conservation farming strategies in East and Southern Africa: yields and rain water productivity from on-farm action research. Soil and Tillage Research 103, 23-32.

Roose, E., Kaboré, V., Guenat, C., 1999. Zaï practice: a West African traditional rehabilitation system for semi-arid degraded lands: a case study in Burkina Faso. Arid Soil Research and Rehabilitation 13, 343-355.

Roupsard, O., Depommier, D., Janodet, E., 1996. Influence de Faidherbia albida sur le sol et le sorgho: Observations dans le parc de Watimona au Burkina Faso. In: Peltier, R. (Ed.), Les parcs à Faidherbia. Cahiers Scientifiques, vol. 12, pp. 141-152.

Roupsard, O., Ferhi, A., Granier, A., Pallo, F., Depommier, D., Mallet, B., Joly, H.I., Dreyer, E., 1999. Reverse phenology and dry-season water uptake by Faidherbia albida (Del.) A. Chev. in an agroforestry parkland of Sudanese west Africa. Functional Ecology 13, 460-472.

Samba, S.A.N., 1997. Influence de Cordyla pinnata sur la fertilité d'un sol ferrugineux tropical sur le mil et l'arachide dans un système agroforestier traditionnel au Sénégal. Thèse de Ph.D. Faculté de Foresterie et de Géomatique, Université Laval, Québec, Canada.

Sanchez, P.A., 1999. Improved fallow come of age in the tropics. Agroforestry Systems 47, 3-12.

Sanou, J., 2010. Optimizing the productivity of agroforestry parkland systems in West Africa using shade-tolerant annual crops. PhD thesis, School of Environment, Natural Resources and Geography, Bangor University, UK.

Sanou, J., Zougmoré, R., Bayala, J., Teklehaimanot, Z., 2010. Soil infiltrability and water content as affected by Baobab (Adansonia digitata L.) and Néré (Parkia biglobosa (Jacq.) Benth.) trees in farmed parklands of West Africa. Soil Use and Management 26, 75-81.

Sanou, J., Bayala, J., Teklehaimanot, Z, Bazie, P. in press. Effect of shading by baobab (Adansonia digitata) and néré (Parkia biglobosa) on yields of millet (Pennisetum glaucum) and taro (Colocasia esculenta) in parkland systems in Burkina Faso, West Africa. Agroforestry Systems 71 (3). doi:10.1007/s10457-011-9405-4.

Segda, Z., Hien, V., Lompo, F., Becker, M., 1998. Gestion améliorée de la jachère par utilisation de légumineuses de couverture. In: Buckles, D., Eteka, A. Osiname, O., Galiba, M., Aliano, G. (Eds.), Plantes de couverture en Afrique de l'Ouest: une contribution à l'agriculture durable, pp. 89-199.

Sidibé, D., 2010. Improving the management and productivity of Ziziphus mauritiana and Tamarindus indica in agroforestry parkland systems in Mali, West Africa. PhD thesis, School of Environment, Natural Resources and Geography, Bangor University, UK.

Sileshi, G., Akinnifesi, F.K., Ajayi, O.C., Place, K., 2008. Meta-analysis of maize yield response to woody and herbaceous legumes in sub-Saharan Africa. Plant and Soil 307, 1-19.

Sileshi, G., Arshad, M.A., Konaté, S., Nkunika, P.O.Y., 2010. Termite-induced heterogeneity in African savanna vegetation: mechanisms and patterns. Journal of Vegetation Science 21, 923-937.

Szott, L.T., Palm, C.A., Buresh, R.J., 1999. Ecosystem fertility and fallow function in the humid and subhumid tropics. Agroforestry Systems 47, 163-196.

Takimoto, A., Nair, R.P.K., Nair, V.D., 2008. Carbon stock and sequestration potential of traditional and improved agroforestry systems in the West African Sahel. Agriculture, Ecosystems \& Environment 125, 159-166.

Thiombiano, L., Meshack, M., 2009. Scaling Up Conservation Agriculture in Africa. Strategy and Approaches. FAO, Addis Ababa, Ethiopia.

Tilander, Y., 1993. Effects of mulching with Azadirachta indica and Albizia lebbeck leaves on the yield of sorghum under semi-arid conditions in Burkina Faso. Agroforestry Systems 24, 277-293.

Tilander, Y., Bonzi, M., 1997. Water and nutrient conservation through the use of agroforestry mulches, and sorghum yield response. Plant and Soil 197, 219-232.

Traoré, K. Bado, V., Hien, V 1998. Effet du mucuna sur la productivité du maïs et du coton. In: Carsky, R.J., Etèka, A.C., Keatinge, J.D.H., Manyong, V.M. (Eds.), Cove Crops for Natural Resource Management in West Africa. Proceedings of a Workshop Organised by IITA and CIEPCA, 26-29 October 1999. Cotonou, Benin, pp. 33-39.

Traoré, K., Zougmoré, R., 2008. Conservation Agriculture in Africa: State of the Art in Burkina Faso. INERA, Burkina Faso.

United Nations Department of Economic and Social Affairs (UN-DESA), 2005. Good Practices in Agricultural Water Management Case Studies from Farmers Worldwide.

United Nations Development Programme (UNDP), 2006. Human Development Report 2006-Beyond Scarcity: Power, Poverty and the Global Water Crisis. UNDP, New York, USA.

Wezel, A., Rath, T., 2002. Resource conservation strategies in agro-ecosystems of semi-arid West Africa. Journal of Arid Environments 51, 383-400. 
Wilson, T.D., Brook, R.M., Tomlinson, H.F., 1998. Interactions between néré (Parkia biglobosa) and under-planted sorghum in parkland system in Burkina Faso. Experimental Agriculture 35, 85-98.

Yaméogo, J., 2008. Contribution des parcs à Borassus akeasii Bayton, Ouédraogo et Guinko au fonctionnement des systèmes de productions dans le sud-ouest du Burkina Faso. Thèse Unique, Université de Ouagadougou, Burkina Faso.

Yossi, H., Traoré, H., Dembélé, F., 2002. Mise au point de technologies agroforestières appropriées RFO 11. Rapport final. IER Sikasso, Mali.

Zomboudré, G., Zombré, G., Ouedraogo, M., Guinko, S., Macauley, H.R., 2005. Réponse physiologique et productivité des cultures dans un système agroforestier traditionnel: cas de maïs (Zea mays L.) associé au karité (Vitellaria paradoxa Gaertn.) dans la zone est du Burkina Faso. BASE 9, 75-85.
Zougmoré, R., Kaboré, P.D., Lowenberg-Deboer, J., 2000. Optimal spacing of soil conservation barriers: example of rock bunds in Burkina Faso. Agronomy Journal 92, 361-368.

Zougmoré, R., Kambou, N.F., Zida, Z., 2003. Role of nutrient amendments in the success of half-moon soil and water conservation practice in semi-arid Burkina Faso. Soil and Tillage Research 71, 143-149.

Zougmoré, R., Ouattara, K., Mando, A., Ouattara, B., 2004. Rôle des nutriments dans le succès des techniques de conservation des eaux et des sols (cordons pierreux, bandes enherbées, zaï et demi-lunes) au Burkina Faso. Sécheresse 15, 41-48.

Zougmoré, R., Mando, A., Ringersma, J., Stroosnijder, L., 2006. Effect of combined water and nutrient management on runoff and sorghum yield in semiarid Burkina Faso. Soil Use and Management 19, 257-264. 